Tropical Journal of Pharmaceutical Research September 2021; 20 (9): 1931-1939

ISSN: $1596-5996$ (print); 1596-9827 (electronic) (C) Pharmacotherapy Group, Faculty of Pharmacy, University of Benin, Benin City, 300001 Nigeria.

\title{
Chemical profiling and anti-breast cancer potential of hexane fraction of Sphaeranthus indicus flowers
}

\author{
Hafiz Majid Rasheed1, Fazli Wahid², Muhammad Ikram¹, Muhammad Qaisar², \\ Abdul Jabbar Shah ${ }^{1}$, Taous Khan ${ }^{1 *}$ \\ ${ }^{1}$ Department of Pharmacy, COMSATS University Islamabad, Abbottabad Campus-22060, ${ }^{2}$ Department of Biomedical Sciences, \\ Pak-Austria Fachhochschule: Institute of Applied Sciences and Technology, Mang, Khanpur Road, Haripur-22620, ${ }^{3}$ Medicinal \\ Botanic Centre, PCSIR Laboratories Complex, Peshawar-25000, Pakistan
}

*For correspondence: Email: taouskhan@cuiatd.edu.pk; Tel: (+92)-992-383591-6; Fax: (+92)992-383441

Sent for review: 3 March 2021

Revised accepted: 21 June 2021

\begin{abstract}
Purpose: The current study aimed to determine the phytochemicals and anti-breast cancer potential of Sphaeranthus indicus.

Methods: S. indicus flowers were extracted with methanol followed by fractionation using $n$-hexane. For the chemical composition of $n$-hexane fraction, qualitative phytochemical and GC-MS analysis were performed. The anti-proliferative activity was measured by MTT assay, whereas, cytotoxic and proapoptotic effects in MCF-7 (breast cancer) cells were determined using propidium iodide, 4', 6-diamidino2-phenylindole, dichlorofluorescin diacetate, and JC-1 staining through fluorescent microscopy.

Results: The phytochemical analysis indicated presence of phytosterols, oils and resins in the $n$ hexane fraction. GC-MS analysis showed that $n$-hexane fraction comprises of 11 compounds including methyl esters of caprylic acid, myristic acid, pentadecanoic acid, palmitic acid, margaric acid, stearic acid, oleic acid, elaidic acid, linoleic acid, linolenic acid and behanic acid. The tested fraction showed remarkable cytotoxic activity against breast cancer (MCF-7) cells while it was found less toxic towards non-cancerous (BHK-21) cells. Furthermore, morphological assessment through fluorescent microscopy revealed cytotoxic and apoptotic effects by improved cell membrane permeability, increased reactive oxygen species level, compromised mitochondrial activity and condensation of chromatin network. Conclusion: The $n$-hexane fraction of S. indicus contains phytosterols, oils and fatty acid methyl esters and produced apoptotic effect against breast cancer cells.
\end{abstract}

Keywords: Apoptosis, DAPI staining, GC-MS, n-Hexane fraction, Reactive oxygen species, Sphaeranthus indicus

\begin{abstract}
This is an Open Access article that uses a funding model which does not charge readers or their institutions for access and distributed under the terms of the Creative Commons Attribution License (http://creativecommons.org/licenses/by/4.0) and the Budapest Open Access Initiative (http://www.budapestopenaccessinitiative.org/read), which permit unrestricted use, distribution, and reproduction in any medium, provided the original work is properly credited.
\end{abstract}

Tropical Journal of Pharmaceutical Research is indexed by Science Citation Index (SciSearch), Scopus, International Pharmaceutical Abstract, Chemical Abstracts, Embase, Index Copernicus, EBSCO, African Index Medicus, JournalSeek, Journal Citation Reports/Science Edition, Directory of Open Access Journals (DOAJ), African Journal Online, Bioline International, Open-J-Gate and Pharmacy Abstracts

\section{INTRODUCTION}

Among cancers, breast cancer is the second leading cause of mortality after the lung cancer. Every year, about one million females are diagnosed with breast cancer worldwide with approximately 410,000 deaths [1]. Males are less prone to this disease and constitutes less than $1 \%$ out of the total diagnosed cases [2,3]. The exact pathophysiology of breast cancer is uncertain in males. The rate of breast cancer 
related mortality continues to increase, especially in less developed countries [4].

Breast cancer is usually caused by the deregulation of molecular players including inflammatory cytokines, tumor suppressor genes, DNA repair genes, proto-oncogenes, growth factor and growth factor receptors. The abnormal increase in interleukins (ILs), nuclear factor kappa-B (NF-kB) and tumor necrosis factors (TNF) normally promote breast cancer. Moreover, down regulation of breast cancer gene 1 (BRCA1), breast cancer gene 2 (BRCA2), p53, ataxia-telangiectasia mutated (ATM) gene and up-regulation of vascular endothelial growth factor receptor (VEGFR), epidermal growth factor receptor (EGFR), platelet-derived growth factor receptor (PDGFR) and HER2/neu also lead to breast cancer [5].

Recently, plant based natural compounds have shown promising anti-cancer activities at cellular, pre-clinical and clinical levels $[6,7]$. Some of these plants derived medicines like podophyllotoxin, vincristine, vinblastine and paclitaxil are in practice for the treatment of various cancers including breast cancer [7]. However, these medicines showed some limitations like non-selectivity, low bioavailability and efficacy, severe side effects or/and are costly.

Sphaeranthus indicus Linn. (Asteraceae) has been reported in traditional medicine for inflammation and breast cancer treatment [8]. Moreover, it is commonly used in Ayurvedic system for the treatment of nervine weakness (as food), epilepsy, mental diseases, diabetes, jaundice and leprosy [9]. This plant contains sterols, peptidal alkaloids, amino acids, essential oils and sugars [10]. The traditional uses of $S$. indicus were scientifically validated by observing its neuroleptic, anxiolytic, anti-inflammatory, immunomodulatory, anti-allergic, hepatoprotective, anti-hyperglycemic and renoprotective activities. Furthermore, anti-hyperlipidemic, bronchodilatory and larvicidal effects of this plant have been reported [8]. The plant is used in traditional system of medicine for the treatment of inflammation and cancer but no comprehensive scientific information are available on the $n$-hexane of $S$. indicus for antibreast cancer activity.

Therefore, based on its ethnomedicinal uses in cancer and other scientific information, this study was designed to investigate the phytochemical and pharmacological potential of $S$. indicus $n$ hexane fraction for in vitro anti-breast cancer activity.

\section{EXPERIMENTAL}

\section{Plant material, extraction and fractionation}

The dried flowers of $S$. indicus were purchased from a local herbal store and the specimen was identified by a plant taxonomist, Hafiz Banaras Khan, Associate Professor, Department of Botany, Government College Attock, Pakistan. A voucher specimen (Akt/103/13) was deposited in the herbarium of the mentioned institute. The $S$. indicus flowers were ground into a fine powder and $10 \mathrm{Kg}$ powdered plant material was extracted by cold maceration in methanol $(25 \mathrm{~L})$ at room temperature and concentrated under vacuum (Rotavapor R-300 system, Buchi, Switzerland) at $40^{\circ} \mathrm{C}$ to afford $1298 \mathrm{~g}$ extract [11].

Methanolic extract $(800 \mathrm{~g})$ was subjected to fractionation by suspending in distilled water and the suspension was further shaken with equal volume of $n$-hexane in separating funnel. The hexane layer was removed and concentrated using rotary evaporator (Rotavapor R-300 system) [12].

\section{Phytochemical analysis}

The n-hexane fraction was screened for various groups of natural products including alkaloids, carbohydrates, phenols, flavonoids, saponins, phytosterols, glycosides, tannins, oils and resins, and proteins as described by Khan et al [12].

\section{Gas chromatography-mass spectrometry of $\mathrm{n}$-hexane fraction}

For the identification and quantification of nhexane fraction of $S$. indicus, gas chromatograph - mass spectrometer (Shimadzu, Japan, Model \# QP2010 plus) was used. GC was equipped with $0.25 \mathrm{~mm}$ (internal diameter) column with $30 \mathrm{~m}$ length and GC condition was set as follows: injector temperature, $240^{\circ} \mathrm{C}$; carrier gas, helium; and flow rate, $1 \mathrm{~mL} / \mathrm{min}$. A $1 \mu \mathrm{L}$ of the sample was injected into the GC system using a split method under the following oven conditions: $50^{\circ} \mathrm{C}$ for $1 \mathrm{~min}$, then $5^{\circ} \mathrm{C} / \mathrm{min}$ to 150 for $0 \mathrm{~min}$, then $2^{\circ} \mathrm{C} / \mathrm{min}$ to $175^{\circ} \mathrm{C}$ for $5 \mathrm{~min}$, then $10^{\circ} \mathrm{C} / \mathrm{min}$ to $220^{\circ} \mathrm{C}$ (end temperature) for $5 \mathrm{~min}$.

In the mass spectrometry (MS) conditions, ion source temperature was set at $250^{\circ} \mathrm{C}$ and interface temperature was $240^{\circ} \mathrm{C}$. Mass scan was started at $1.65 \mathrm{~min}$ and ended at $47 \mathrm{~min}$ at a range of $85-380 \mathrm{~m} / \mathrm{z}$. The obtained spectrum was compared with the fragmentation pattern available with the NIST (NIST 05) Library [13]. 


\section{Cytotoxicity and anti-cancer activity}

\section{Cell culture}

The cytotoxicity of $n$-hexane fraction was evaluated against normal fibroblast (BHK-21) cells. Similarly, the anti-cancer effect was evaluated against adherent breast cancer MCF-7 cells. These cells were acquired from American Type Culture Collection (ATCC, Rockville, MD, USA) and both activities were evaluated through MTT assay [14]. The cells were cultured in Dulbecco's modified Eagle's medium (DMEM) containing $10 \%$ FBS, $100 \mathrm{U} \mathrm{mL}^{-1}$ penicillin, and streptomycin (all from Gibco/Invitrogen Life Technologies, US) at $37^{\circ} \mathrm{C}$ in a $\mathrm{CO}_{2}$ incubator. Sub confluent cells were harvested with trypsinEDTA and used for further experiments. Media were replaced every third day.

\section{MTT assay}

For MTT assay, cells at concentration of $1 \times 10^{4}$ cells/well were seeded into 96-well flat-bottom culture plates (Costar $®$, Corning Inc., Corning, NY, USA). Each well was supplied with $0.1 \mathrm{~mL}$ DMEM media. After $24 \mathrm{~h}$ culture (at about $70 \%$ confluence), cells were treated with 31.25-500 $\mu \mathrm{g} / \mathrm{mL}$ of $n$-hexane fraction for $48 \mathrm{~h}$ in fresh medium. After that, media was replaced in each well with serum free media containing MTT reagent (BioShop Canada Inc. Burlington, Ontario, Canada) (1:10). The plates were further incubated at $37^{\circ} \mathrm{C}$ (under $5 \% \mathrm{CO}_{2}$ ) for additional $4 \mathrm{~h}$ in a humidified environment. After media aspiration, formazan crystals were dissolved with DMSO $(100 \mu \mathrm{L})$. Absorbance of the formazan dye, generated by the reaction between dehydrogenase and MTT in metabolically active cells, was measured using a microplate reader (Tecan, Switzerland) at $492 \mathrm{~nm}$. Experiments were performed at least thrice. Dimethyl sulphoxide $(0.03-1 \%)$ was used as negative control. The percent inhibition of the cells was calculated using the formula:

\section{W Wabulty $=\frac{\text { Ahsorhamef of sample }}{\text { Absorbanga of afgatlw sontrol }} \times 100$}

\section{Propidium iodide staining}

The $n$-hexane fraction was subjected to microscopic analysis for apoptosis using previously reported methods [15]. Confluent MCF-7 cells $\left(2 \times 10^{5}\right.$ cells/well) were treated with 125 and $250 \mu \mathrm{g} / \mathrm{mL}$ of the fraction, doxorubicin (5 and $10 \mu \mathrm{g} / \mathrm{mL}$ ) (standard) and vehicle followed by incubation at $37^{\circ} \mathrm{C}\left(5 \% \mathrm{CO}_{2}\right.$ incubator) for 48 $\mathrm{h}$. Then, the media was aspirated and breast cancer cells were washed with phosphate buffer saline. After washing, cells were treated with formalin (4\%) and fixed with Triton X-100 (0.1\%) on glass slides. After $5 \mathrm{~min}$ of room incubation, propidium iodide $(10 \mu \mathrm{L})$ dye was mixed and glass slides were further incubated for $10 \mathrm{~min}$ in dark. The images of slides were captured (at 20X magnification) at an excitation/emission wavelength of 493/632 nm using fluorescent microscope (Nikon, ECLIPSE Ni-U, Tokyo, Japan).

\section{4', 6-Diamidino-2-phenylindole staining}

The DAPI staining was used to investigate induction of apoptosis by selected fraction and doxorubicin. Briefly, MCF-7 cells were seeded in 24-well plate. Confluent cells $(80 \%)$ were exposed to different concentrations of selected sample for $48 \mathrm{~h}$ at $37^{\circ} \mathrm{C}$. After this, cancer cells were gently washed with PBS and fixed with formalin. Then, the cells were immediately treated with DAPI stain for $5 \mathrm{~min}$. Later, these cancer cells were imaged using florescence microscope using 20X lens (Nikon, ECLIPSE NiU) [15].

\section{Investigation of intracellular reactive oxygen species (ROS) production}

The ROS production in breast cancer (MCF-7) cells by different concentrations (125 and 250 $\mu \mathrm{g} / \mathrm{mL}$ ) of $n$-hexane fraction, doxorubicin (5 and $10 \mu \mathrm{g} / \mathrm{mL}$ ) (standard drug) and vehicle was assessed using previously described method [16]. Briefly, MCF-7 cells $\left(2 \times 10^{5}\right)$ were seeded and grown on microscopic coverslips. These cells were treated with tested samples for $48 \mathrm{~h}$. Then, the cells were washed and fixed, and were treated with dichlorofluorescin diacetate (H2DCFDA) dye $(10 \mu \mathrm{L})$. Cells treated were incubated at room temperature for $10 \mathrm{~min}$ in the dark. Images of the cells were captured (at 20X magnification) at $488 / 530 \mathrm{~nm}$ excitation/emission filters using fluorescence microscope (Nikon ECLIPSE Ni-U).

\section{Measurement of mitochondrial membrane potential $(\Delta \Psi \mathrm{m})$}

The change in mitochondrial membrane potential of MCF-7 cells, after treating with n-hexane fraction, was observed using JC-1 staining. The $\mathrm{JC}-1$ probe is dimerized in cells having functional mitochondria and form aggregates, which emits red fluorescence. On the other hand, it exists in monomeric form in cells that have lost mitochondrial activity (early apoptosis) and emits green fluorescence. Briefly, the MCF-7 breast cancer cells, at a density of $2 \times 10^{5}$ cells/well were seeded in 24-well plate with $1 \mathrm{~mL}$ complete growth medium and incubated for $12 \mathrm{~h}$ (cells 
allowed to adhere). Next, the confluent cancer cells $(70-80 \%)$ were treated with $125 \mu \mathrm{g} / \mathrm{mL}$ of $\mathrm{n}-$ hexane fraction and $10 \mu \mathrm{g} / \mathrm{mL}$ standard drug (doxorubicin). After treatment for $48 \mathrm{~h}$, medium was removed and the cells were once washed with PBS. Then, cells were fixed with formalin and incubated with $10 \mu \mathrm{L} \mathrm{JC}-1$ fluorescent dye for $30 \mathrm{~min}$ in the dark at $37^{\circ} \mathrm{C}$. The cells were imaged for any change in mitochondrial potential using a fluorescence microscope (Nikon, ECLIPSE Ni-U) at $550 \mathrm{~nm}$ excitation and $570 \mathrm{~nm}$ emission wavelength [16].

\section{Statistical analysis}

Data are presented with mean \pm standard error of the mean (SEM) with confidence interval $(\mathrm{Cl})$ of $95 \%$. The results were statistically analyzed for three independent experiments using twotailed Student's t-test by applying GraphPad prism (version 5.0) software.

\section{RESULTS}

\section{Phytochemical analysis}

The n-hexane fraction of $S$. indicus was subjected to phytochemical analysis, which indicated the presence of phytosterols, and oils and resins.

\section{GC-MS analysis of $n$-hexane fraction}

The GC-MS analysis led to the identification of eleven chemical constituents (99.99\%). Methyl esters of linoleic acid $(42.58 \%)$, palmitic acid $(36.43 \%)$, stearic acid $(8.14 \%)$, behanic acid $(4.30 \%)$, oleic acid $(3.45 \%)$ and linolenic acid $(1.62 \%)$. The others were methyl esters of myristic acid (0.94\%), margaric acid (0.90\%), pentadecanoic acid $(0.67 \%)$, caprylic acid $(0.56 \%)$ and elaidic acid $(0.40 \%)$ (Table 1$)$.

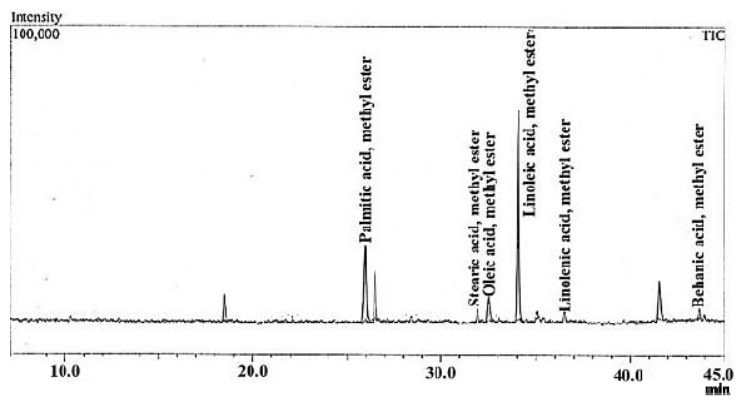

Figure 1: GC-MS chromatogram of some identified constituents in the $n$-hexane fraction of $S$. indicus.

\section{Cytotoxicity assessments and anti-cancer activity}

In the current study, $n$-hexane of $S$. indicus showed remarkable anti-proliferative effect against breast cancer cells (Figure 2A). The treatment with fraction for $48 \mathrm{~h}$ showed significant reduction $(90.36 \pm 0.12)$ in MCF-7 cells viability (\% cell death) in comparison to control (0) and doxorubicin, a standard drug (97.16 \pm 0.28$)$ (Figure 2B). The respective $I_{50}$ values of fraction and doxorubicin after $48 \mathrm{~h}$ of treatment are 2.39 and $1.89 \mu \mathrm{g} / \mathrm{mL}$. However, it was observed that $n$-hexane fraction induced lower toxicity to BHK-21 (normal) cells in comparison to standard doxorubicin as shown in Figure $2 \mathrm{C}$ and $2 \mathrm{D}$, respectively.

\section{Determination of cytotoxic activity through fluorescence microscopy}

The appearance of yellowish red fluorescence, after PI staining, confirmed the cytotoxic effect of $n$-hexane fraction in apoptotic breast cancer cells (Figure 3).

Table 1: Chemical composition of $n$-hexane fraction from $S$. indicus flowers analyzed by GC-MS. RT is indicated for the retention time on chromatogram

\begin{tabular}{lccc}
\hline \multicolumn{1}{c}{ Compound name } & RT (min) & Area & Concentration (\%) \\
\hline${ }^{*}$ C8:0; Caprylic acid, methyl ester & 7.803 & 707 & 0.56 \\
${ }^{*}$ C14:0; Myristic acid, methyl ester & 21.182 & 1189 & 0.94 \\
${ }^{*}$ C15:0; Pentadecanoic acid, methyl ester & 23.387 & 846 & 0.67 \\
C16:0; Palmitic acid, methyl ester & 25.962 & 45919 & 36.43 \\
${ }^{*}$ C17:0; Margaric acid, methyl ester & 28.810 & 1138 & 0.90 \\
C18:0; Stearic acid, methyl ester & 31.962 & 10260 & 8.14 \\
C18:1c; Oleic acid, methyl ester & 32.502 & 4353 & 3.45 \\
*C18: 1n9t; Elaidic acid, methyl ester & 32.704 & 499 & 0.40 \\
C18:2c; Linoleic acid, methyl ester & 34.080 & 53675 & 42.58 \\
C18:3n3; Linolenic acid, methyl ester & 36.520 & 2042 & 1.62 \\
C22:0; Behanic acid, methyl ester & 43.644 & 5417 & 4.30 \\
\hline
\end{tabular}

${ }^{*}$ Constituents detected by the instrument but not visible in the chromatogram due to lower concentration $(<1 \%)$. Calculation of percentages were based on the compounds detected 

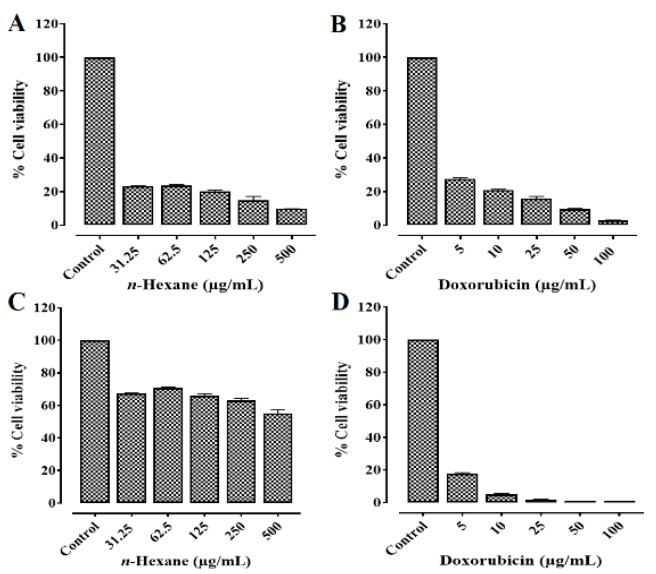

Figure 2: Graphical presentation of respective inhibitory effect of $S$. indicus $n$-hexane fraction (31.25$500 \mu \mathrm{g} / \mathrm{mL})$ and doxorubicin $(5-100 \mu \mathrm{g} / \mathrm{mL})$ on MCF-7 (A, B) and BHK-21 (C, D) cells proliferation in a dose dependent manner. The results are expressed as the percentage of control
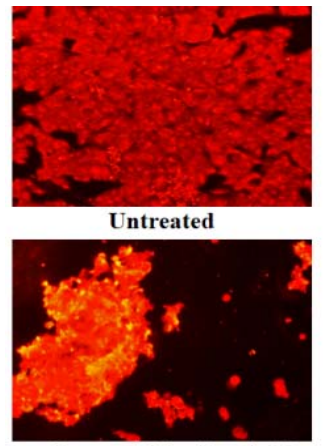

Doxorubicin $(5 \mu \mathrm{g} / \mathrm{mL})$

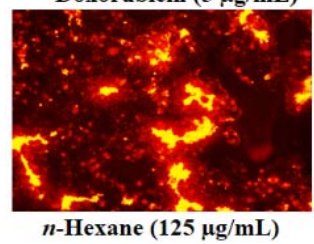

Figure 3: Representative images of changes in the nuclear morphology of MCF-7 cells induced by 125 and $250 \mu \mathrm{g} / \mathrm{mL}$ of $S$. indicus $n$-hexane fraction in comparison to standard drug (doxorubicin 5 and 10 $\mu \mathrm{g} / \mathrm{mL})$, vehicle treated $(0.5 \%$ DMSO) and control (untreated) after PI staining.

\section{Determination of apoptosis by DAPI staining}

Breast cancer cells were stained with DAPI (a fluorescent dye) to assess the apoptosis after 48 $\mathrm{h}$ of treatment with fraction and standard drug. The images obtained through fluorescent microscopy revealed the binding of DAPI with the DNA of apoptotic cells (Figure 4). Moreover, apoptotic features like cellular shrinkage and condensation of nuclear material were observed as shown in Figure 4.
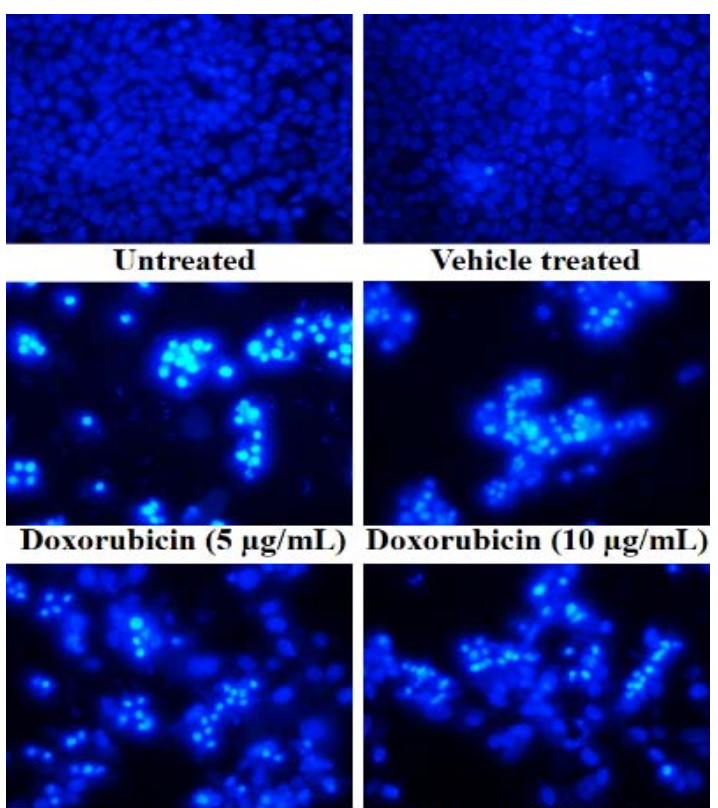

n-Hexane $(125 \mu \mathrm{g} / \mathrm{mL})$

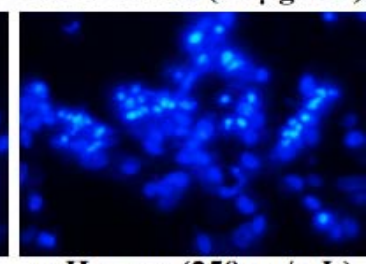

$n$-Hexane $(250 \mu \mathrm{g} / \mathrm{mL})$

Figure 4: Representative images of changes in the nuclear morphology of MCF-7 cells induced by 125 and $250 \mu \mathrm{g} / \mathrm{mL}$ of $S$. indicus $n$-hexane fraction in comparison to standard drug (doxorubicin 5 and 10 $\mu \mathrm{g} / \mathrm{mL}$ ), vehicle treated and control (untreated) after DAPI staining

\section{Intracellular ROS production}

In the current study, 125 and $250 \mu \mathrm{g} / \mathrm{mL}$ of $n$ hexane fraction produced ROS comparable to doxorubicin (5 and $10 \mu \mathrm{g} / \mathrm{mL}$ ) in MCF-7 (breast cancer) cells, which was detected by staining with 2',7'-dichlorofluorescin diacetate (H2DCFDA). A difference in treated and untreated cells by integrity of cell membrane and intense green fluorescence can be observed in Figure 5.

\section{Mitochondrial membrane potential}

There was considerable loss in mitochondrial membrane potential in MCF-7 cells after treatment with tested sample in comparison to control. Figure 6 shows the fluorescence conversion from red to green in response to treatment with $n$-hexane fraction and standard drug, which indicates early apoptosis in cancer cells.

\section{DISCUSSION}

In this study, GC-MS analysis of n-hexane fraction from $S$. indicus indicated the presence of 11 fatty acids methyl esters. The n-hexane fraction exhibited significant cytotoxic and proapoptotic effects in MCF-7 cells. Similarly, an increased oxidative stress and mitochondrial dysfunction in MCF-7 cells treated with n-hexane 
fraction revealed the involvement of intrinsic pathway for the induction of apoptosis.
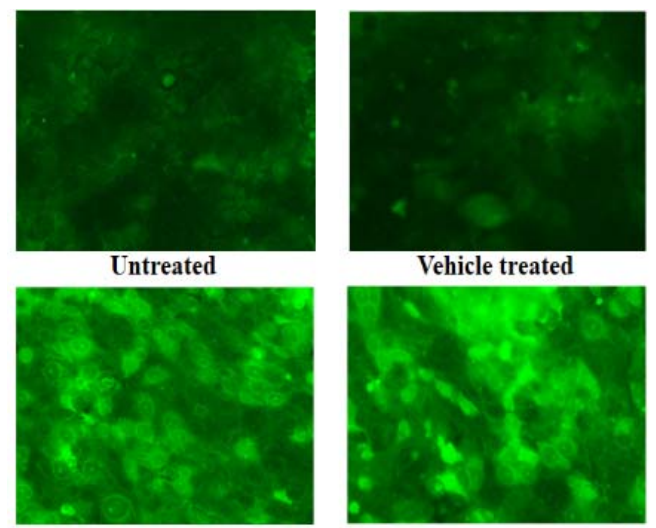

Vehicle treated

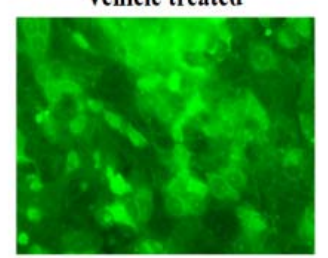

Doxorubicin $(5 \mu \mathrm{g} / \mathrm{mL})$

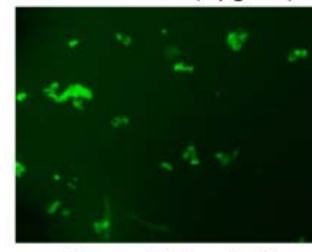

n-Hexane $(125 \mu \mathrm{g} / \mathrm{mL})$

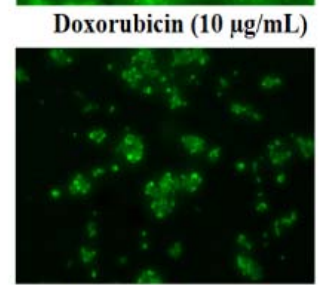

$n$-Hexane $(250 \mu \mathrm{g} / \mathrm{mL})$

Figure 5: Representative images of oxidized dichlorofluorescein fluorescence of MCF-7 cells induced by 125 and $250 \mu \mathrm{g} / \mathrm{mL}$ of $S$. indicus $n$-hexane fraction in comparison to standard drug (doxorubicin 5 and $10 \mu \mathrm{g} / \mathrm{mL}$ ), vehicle treated and control (untreated) after treatment with 2', 7'dichlorodihydrofluorescein diacetate.

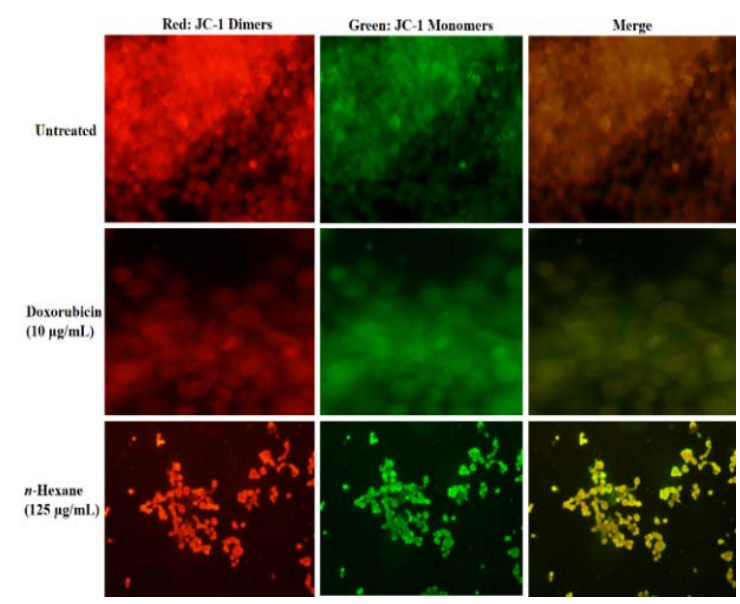

Figure 6: Representative images of morphological changes in MCF-7 cells induced by $125 \mu \mathrm{g} / \mathrm{mL}$ of $S$. indicus $\mathrm{n}$-hexane fraction in comparison to standard drug (doxorubicin $10 \mu \mathrm{g} / \mathrm{mL}$ ) and control (untreated) after JC-1 staining.

Using GC-MS analysis, fats and oils, previously reported in the $n$-hexane fraction of $S$. indicus flowers [17], were also detected in the current study. However, detection of hexose sugars in the same fraction [17] could not be confirmed in this study. This variation in chemical composition of secondary metabolites might be due to various factors like extraction procedure, solvents, habitat, edaphic factors and climate conditions [13]. In GC-MS analysis, most of the identified constituents have been reported to possess important biological activities. For example, linoleic acid, palmitic acid, linolenic acid, pentadecanoic acid, oleic acid and stearic acid have cytotoxic activity against various cancer cell lines [18-22]. On the basis of the available information; it is assumed that the anti-breast cancer effect of $n$-hexane fraction may be due to the presence of fatty acid methyl esters. Natural compounds may have beneficial or deleterious effects depending on their chemical nature and mode of utilization. In disease management, safety is the main concern for development of novel therapeutics [23]. In this study, a less cytotoxic activity of $n$-hexane fraction against non-cancerous cells demonstrated a good safety margin of the tested sample. Based on earlier report [24], selectively targeting of cancer cells with minimum toxicity to normal cells prevents damaging effects on body organ or tissues. However, significant reduction in viable breast cancer cells revealed tremendous antiproliferative effect that may be attributed to the presence of linoleic acid and steric acid (major constituents), which have been reported earlier for their anti-breast cancer activities [18-20]. These results indicated the potential of $n$-hexane fraction for the development of anti-breast cancer molecules. However, to validate these in vitro studies, pre-clinical and clinical investigations are needed to have an insight into further details regarding the efficacy and safety of $S$. indicus flowers.

PI, a light sensitive, membrane impermeable and hydrophilic fluorescent dye, binds to nucleic acids inside the apoptotic or dead cells [25]. PI staining is used to differentiate live from dead cells. In the current study, the presence of a large population of cells with intense yellowish fluorescence indicated the cytotoxic potential of the tested fraction. Apoptotic cells have characteristic features like chromatin condensation, nuclear fragmentation, membrane blebbing and formation of apoptotic bodies [26]. In DAPI staining, an increase in bluish fluorescence indicated the binding of the dye with DNA after penetration into the cells due to increased membrane permeability. Additionally, nuclear condensation and cell shrinkage was observed in treated cancer cells as compared to the control cells, which confirmed the proapoptotic potential of $n$-hexane fraction. These data supported the results of PI staining. 
Reactive oxygen species are produced in mitochondria normally in a low amount and play vital roles in different signaling pathways [27]. Cancer cells have a moderately increased ROS level due to higher metabolic rate and hypoxic conditions, which helps these cells to proliferate and progress rapidly [28]. However, a much higher ROS levels are lethal to cells. Thus, cancer cells are more prone to apoptosis as compared to normal cells when treated with ROS inducing compounds [29]. 2',7'-Dichlorodihydrofluorescein diacetate (H2DCF-DA) is a non-fluorescent, cell permeable and most commonly used reagent for measuring ROS in cells [30]. After diffusion into the cells, H2DCFDA is converted into a highly fluorescent product 2',7'-dichloro-fluorescein (DCF) by ROS [31]. Treated cancer cells, in present study, showed dose dependent DCF fluorescence. This confirmed the apoptosis in these cells due to overproduction of ROS in a similar manner as reported previously [32]. These results showed that the tested sample has an ability to induce ROS generation in breast cancer cells for apoptotic activity.

$\mathrm{JC}-1$ is an excellent fluorescent stain and it is commonly used for the detection of mitochondrial membrane potential in tissues or cells [33]. When the mitochondrial membrane potential is increased, JC-1 accumulates in mitochondria forming J-aggregates (red fluorescence) [34]. Contrarily, when mitochondrial membrane potential is reduced, JC-1 cannot accumulate in mitochondrial environment and JC-1 monomers with the green fluorescence are produced [35]. Therefore, mitochondrial membrane potential can be easily determined based on this fluorescence color change. A decrease in mitochondrial membrane potential is a sign of an early apoptosis [36]. The current study revealed an intense green fluorescence as compared to red fluorescence in fraction treated cancer cells, which is an indicative of early apoptosis in breast cancer MCF-7 cells due to mitochondrial dysfunction.

\section{CONCLUSION}

The GC-MS analysis results suggested that $n$ hexane fraction of $S$. indicus is highly rich in fatty acids. Moreover, current study demonstrated that $n$-hexane fraction induced apoptosis in MCF-7 cells possibly through nuclear condensation, ROS generation and mitochondrial dysfunction pathways. Anti-cancer and apoptotic properties of $n$-hexane fraction may be attributed to linoleic acid (a major constituent). Therefore, phytoconstituents identified in this study may serve as potential candidates for the development of antibreast cancer agents for clinical applications.

\section{DECLARATIONS}

\section{Funding}

This study was supported by the Higher Education Commission of Pakistan under National Research Program for Universities (NRPU) (Grant No-20-3666/R\&D/HEC/14).

\section{Acknowledgement}

The authors are thankful to Prof. Dr. Jamshed Iqbal, Centre for Advanced Drug Research, COMSATS University Islamabad, Abbottabad Campus for providing the facilities for fluorescent microscopy.

\section{Conflicts of interest}

Authors have no conflict of interest.

\section{Availability of data and material}

Full data is available on reasonable request.

\section{Ethics approval}

The study was approved by the ethical committee of Department of Pharmacy, CUI, Abbottabad Campus, Pakistan.

\section{Authors' contributions}

All authors reviewed the manuscript and give consent for publication. TK, FW and AJS conceived the project, supervised the research, and reviewed the manuscript. $\mathrm{HMR}, \mathrm{MI}$ and $\mathrm{MQ}$ designed and performed the experiments, analyzed the results, wrote the manuscript as well as prepared the figures. We declare that this work was done by the authors named in this article and all liabilities pertaining to claims relating to the content of this article will be borne by the authors.

\section{Open Access}

This is an Open Access article that uses a funding model which does not charge readers or their institutions for access and distributed under the terms of the Creative Commons Attribution License (http://creativecommons.org/licenses/by/ 4.0) and the Budapest Open Access Initiative (http://www.budapestopenaccessinitiative.org/rea d), which permit unrestricted use, distribution, 
and reproduction in any medium, provided the original work is properly credited.

\section{REFERENCES}

1. He L, Wang $X$, Ma $Q$, Zhao W, Jia Y, Dong G, Zhu Y, Jia $X$, Tong $Z$. Glycyrrhizin inhibits the invasion and metastasis of breast cancer cells via upregulation of expressions of miR-200c and e-cadherin. Trop J Pharm Res 2020; 19: 1807-1813.

2. Ly $D$, Forman $D$, Ferlay J, Brinton LA, Cook MB. An international comparison of male and female breast cancer incidence rates. Int J Cancer 2013; 132: 19181926.

3. Siegel RL, Miller KD, Jemal A. Cancer statistics, 2015. CA Cancer J Clin 2015; 65: 5-29.

4. Bines J, Eniu A. Effective but cost-prohibitive drugs in breast cancer treatment. Cancer 2008; 113: 2353-2358.

5. Vuong D, Simpson PT, Green B, Cummings MC, Lakhani SR. Molecular classification of breast cancer. Virchows Arch 2014; 465: 1-14.

6. Petrovska BB. Historical review of medicinal plants' usage. Pharmacogn Rev 2012; 6: 1-5.

7. Iqbal J, Abbasi BA, Mahmood T, Kanwal K, Ali K, Shah SA, Khalil AT. Plant-derived anticancer agents: a green anticancer approach. Asian Pac J Trop Biomed 2017; 7: 1129-1150.

8. Galani VJ, Patel BG, Rana DG. Sphaeranthus indicus Linn: A phytopharmacological review. Int J Ayurveda Res 2010; 1: 247-253.

9. Harshal AP, Deepika T. A comprehensive review on Sphaeranthus indicus Linn. Global J Res Med Plants Indigen Med 2012; 1: 404-410.

10. Ramachandran S. Review on Sphaeranthus indicus Linn. (Kottaikkarantai). Pharmacog Rev 2013; 7: 157-169.

11. Saeed A, Wahid F, Rasheed HM, Qayyum R, Shah AJ, Khan T. Effects of Heliotropium strigosum and Trapa bicornis in hyperactive gut disorders. Bangladesh $J$ Pharmacol 2017; 12: 190-196.

12. Khan T, Ali S, Qayyum R, Hussain I, Wahid F, Shah AJ. Intestinal and vascular smooth muscle relaxant effect of Viscum album explains its medicinal use in hyperactive gut disorders and hypertension. BMC Complement Altern Med 2016; 16: 251.

13. Rasheed HM, Khan T, Wahid F, Khan R, Shah AJ. Chemical composition and vascular and intestinal smooth muscle relaxant effects of the essential oil from Psidium guajava fruit. Pharm Biol 2016; 54: 2679-2684.

14. Sepehr KS, Baradaran B, Mazandarani M, Yousefi B, Alitappeh MA, Khori V. Growth-inhibitory and apoptosisinducing effects of Punica granatum L. var. spinosa (Apple Punice) on fibrosarcoma cell lines. Adv Pharm Bull 2014; 4(2): 583-590.

15. Lin GJ, Jiang GB, Xie YY, Huang HL, Liang ZH, Liu YJ. Cytotoxicity, apoptosis, cell cycle arrest, reactive oxygen species, mitochondrial membrane potential, and Western blotting analysis of ruthenium (II) complexes. $J$ Biol Inorg Chem 2013; 18: 873-882.
16. Rastogi RP, Singh $S P$, Häder DP, Sinha RP. Detection of reactive oxygen species (ROS) by the oxidant-sensing probe 2', 7'-dichlorodihydrofluorescein diacetate in the cyanobacterium Anabaena variabilis PCC 7937. Biochem BiophysRes Comm 2010; 397: 603-607.

17. Singh S, Semwal BC, Neeli GS. Microscopic and physicochemical evaluation of leaves of Sphaeranthus indicus Linn. Pharmacogn J 2017; 9: 21-26.

18. Jóźwiaka $M$, Filipowskab $A$, Fiorinoc $F$, Struga $M$. Anticancer activities of fatty acids and their heterocyclic derivatives. Eur J Pharmacol 2020; 871: 172937.

19. Narayanan A, Baskaran SA, Amalaradjou MAR, Venkitanarayanan $K$. Anticarcinogenic properties of medium chain fatty acids on human colorectal, skin and breast cancer cells in vitro. Int J Mol Sci 2015; 16: 50145027.

20. To NB, Nguyen YTK, Moon JY, Ediriweera MK, Cho SK. Pentadecanoic acid, an odd-chain fatty acid, suppresses the stemness of MCF-7/SC human breast cancer stemlike cells through JAK2/STAT3 signaling. Nutrients 2020; 12: 1663.

21. Li J, Rao H, Bin Q, Fan YW, Li HY, Deng ZY. Linolelaidic acid induces apoptosis, cell cycle arrest and inflammation stronger than elaidic acid in human umbilical vein endothelial cells through lipid rafts. Eur J Lipid Sci Technol 2016; 119: 1600374.

22. Mason JK, Klaire S, Kharotia S, Wiggins AKA, Thompson $L U$. a-linolenic acid and docosahexaenoic acid, alone and combined with trastuzumab, reduce HER2overexpressing breast cancer cell growth but differentially regulate HER2 signaling pathways. Lipids Health Dis 2015; 14: 91.

23. Morobe IC, Mthethwa NS, Bisi-Johnson MA, Vasaikar $S D$, Obi CL, Oyedeji AO, Kambizi L, Eloff JN, Hattori $T$. Cytotoxic effects and safety profiles of extracts of active medicinal plants from South Africa. J Microbiol Res 2012; 2: 176-182.

24. Rahman SASN, Abdul Wahab N, Abd Malek SN. In vitro morphological assessment of apoptosis induced by antiproliferative constituents from the rhizomes of Curcuma zedoaria. Evid Based Complement Alternat Med 2013; 2013: 257108

25. Strauber $H$, Muller S. Viability states of bacteria-specific mechanisms of selected probes. Cytometery 2010; 77A: 623-634.

26. Doonan F, Cotter TG. Morphological assessment of apoptosis. Methods. 2008; 44: 200-204.

27. Zhang J, Wang X, Vikash V, Ye Q, Wu D, Liu Y, Dong W. ROS and ROS-mediated cellular signaling. Oxid Med Cell Longev 2016; 2016: 4350965.

28. Perillo B, Donato MD, Pezone A, Zazzo ED, Giovannelli $P$, Galasso G, Castoria G, Migliaccio A. ROS in cancer therapy: the bright side of the moon. Exp Mol Med 2020; 52: 192-203.

29. Reczek CR, Chandel NS. The two faces of reactive oxygen species in cancer. Annu Rev Cancer Biol 2017; 1: $79-98$.

Trop J Pharm Res, September 2021; 20(9): 1938 
30. Kalyanaraman B, Darley-Usmar V, Davies KJ, Dennery PA, Forman HJ, Grisham MB, Mann GE, Moore K, II $L J R$, Ischiropoulos $H$. Measuring reactive oxygen and nitrogen species with fluorescent probes: challenges and limitations. Free Radic Biol Med 2012; 52: 1-6.

31. Circu ML, Aw TY. Reactive oxygen species, cellular redox systems, and apoptosis. Free Radic Biol Med 2010; 48: 749-762.

32. Chen Z, Jin K, Gao L, Lou G, Jin Y, Yu Y, Lou Y. Antitumor effects of bakuchiol, an analogue of resveratrol, on human lung adenocarcinoma A549 cell line. Eur J Pharmacol 2010; 643: 170-179.

33. Tai Y, Sun YM, Zou X, Pan Q, Lan YD, Huo Q, Zhu JW, Guo F, Zheng CQ, Wu CZ, Liu H. Effect of Polygonatum odoratum extract on human breast cancer MDA-MB-231 cell proliferation and apoptosis. Exp Ther Med 2016; 12: 2681-2687.

34. Castedo M, Ferri K, Roumier T, Métivier D, Zamzami N, Kroemer G. Quantitation of mitochondrial alterations associated with apoptosis. J Immunol Methods 2002; 265: 39-47.

35. Baxa DM, Luo X, Yoshimura FK. Genistein induces apoptosis in $T$ lymphoma cells via mitochondrial damage. Nutr Cancer 2005; 51: 93-101.

36. Wang L, Yao SM, Wang Q. The mechanism of mitochondrial impairment induced by cadmium. Huan Jing Yu Zhi Ye Yi Xue 2006; 23: 73-75. 